\title{
Population structure and distribution of Abies spectabilis (D. Don) in Central Nepal Himalaya: A comparison with the total woody vegetation of the forests at the three different elevation ranges in Manang District
}

\author{
D. K. Kharal ${ }^{1,2}$, D. R. Bhuju ${ }^{3}$, N. P. Gaire ${ }^{3,4}$, S. Rayamajhi ${ }^{1}$, H. Meilby ${ }^{5}$, and
}

A. Chaudhary ${ }^{2}$

Population structure and distribution of vegetation are often affected by elevation induced climate variation in the Himalaya. This research aims at assessing the population structure and distribution of Abies spectabilis in three different elevation sites within the forests areas in Manang District of central Nepal. Vegetation sampling was conducted during Sept-Oct 2012 and the population information of all the woody vegetation from a total of 59 concentric circular sampling plots of $10 \mathrm{~m}$ radii along the transect line were collected. The middle elevation site was characterized by the highest density of seedlings $(15,044 / \mathrm{ha})$, saplings $(1,629 / \mathrm{ha})$, poles $(272 / \mathrm{ha})$ and trees $(179 /$ ha) of all woody vegetation. In this elevation, the highest proportion was contributed by $A$. spectabilis (54\%) at combined-level in spite of the lack of large-sized stems (dbh $>70 \mathrm{~cm})$. The proportion of $A$. spectabilis stem was nearly one-fourth of all the woody vegetation while its lowest proportion (15.5\%) was found at the lower elevation at combined-level. On the contrary, its basal area proportion was nearly the half of all the woody vegetation at the lower elevation site, nearly one-third at the middle elevation site and less than $10 \%$ at the upper elevation site. There was a significant variation in mean density and basal areas of all stem categories among the sampled sites except the seedling density of all the woody vegetation between the lower and the middle elevations. The stem distribution of all the woody vegetation including $A$. spectabilis demonstrated the characteristics of normal (sustainable) forest in Manang District. The presence of only small-sized trees with good recent regeneration of $A$. spectabilis in the upper treeline ecotone revealed stand densification as well as its potential for upward migration in response to environmental change including climate change in future.

Key words: Basal area, ecology, forests, stems distribution

$\mathbf{F}^{\mathrm{o}}$ orest is one of the crucial resources for providing various kinds of goods and ecosystem services to the large proportion of the people in the Himalaya. Environmental change including rapidly happening climate change has widely affected forest ecosystems (IPCC, 2014). Community structure, composition and vegetative function are the most important ecological attributes of forests, which show variations in response to environmental as well as anthropogenic variables (Wangda and Ohshwa, 2006; Moktan et al., 2009; Shaheen et al., 2012).

The Himalaya region is very sensitive and

vulnerable to environmental changes in the world and, therefore, exposed to strong environmental impacts from any changes in its climate (HMGN/ MFSC, 2002; WECS, 2002; WWF Nepal, 2006; ICIMOD, 2010; GoN/MoE， 2010). Climate change is a major concern in the Himalaya because of its adverse impacts on the economy, ecology and environment of the region including down-stream areas. Studies have revealed that the temperature rise in Nepal is more pronounced at higher elevation (Shrestha et al., 1999). Rapid climate change has many biophysical impacts (IPCC, 2014) including change in species composition of ecological communities,

\footnotetext{
${ }^{1}$ Institute of Forestry (IOF), Tribhuvan University (TU), Pokhara, Nepal. E-mail: deepak_kharal@yahoo.com

2 Department of Forest Research and Survey, Kathmandu, Nepal

${ }^{3}$ Nepal Academy of Science and Technology, Lalitpur, Nepal

${ }^{4}$ Central Department of Environmental Science, TU, Kathmandu, Nepal

5 University of Copenhagen, Denmark
} 
range and distribution shift of species as well as changes in phenology of the organisms (Root et al., 2003; Parolo and Rossi, 2008; Chen et al., 2011; Gottfried et al., 2012; Webb et al., 2012). Although several studies have analyzed the altitudinal and latitudinal forest zones in relation to climate of the Himalaya, very little is known on the comparative ecology and regeneration dynamics of the forests along the elevation gradient in Nepal Himalaya. Studies along the elevation gradients are important, because many abiotic factors including temperature change with elevation.

Abies spectabilis (D. Don) is a high altitude Himalayan fir found in central to western Nepal, up to Afghanistan in the west, between 2400$4400 \mathrm{~m}$ elevations at temperate and alpine zones (Stainton, 1972; Jackson, 1994; Yadav et al., 2004; Ghimire et al., 2008). It extends up to the treeline, and Betula utilis forest succeeds at higher altitudes (Ghimire et al., 2008; Sujakhu et al., 2013). Among the several Himalayan conifers, A. spectabilis is proved for its dendroclimatic potential along the entire Himalayan range (Suzuki, 1990; Bhattacharyya et al., 1992; Yadav and Singh, 2002; Yadav et al., 2004; Sano et al., 2005; Gaire et al., 2011, 2014). Trees at treeline often respond to climatic warming with increase in recruitment or tree-density, as well as upward advances in the treeline (Bradley and Jones, 1993; Camarero and Gutiérrez, 2004; Kullman, 1998; Gaire et al., 2014; Chhetri and Cairns, 2015). At the margin of a species' natural distribution range, climate is usually a limiting factor for growth and, therefore, climatic effects on tree growth increase when approaching the very margin of the natural distribution range (Fritts, 1976; Schweingruber, 1996). The A. spectabilis at the treeline is responding to climate change with increase in tree density as well as upward shifting of upper distribution limit (Gaire et al., 2011, 2014; Chhetri and Cairns, 2015). However, little is known about its ecological response with climate change, considering regeneration dynamics along an elevation gradient. This tree line species could be important source for understanding of past climate in the Himalayas and, hence, it is necessary to understand the distribution pattern of this species and in particular the current regeneration status and its growth trend in the Manang Valley of Nepal. The specific goal of present study was to investigate regeneration dynamics of $A$. spectabilis based on their population structure, seedling/sapling densities along the elevation gradient of Manang District.

\section{Materials and methods}

\section{Study area}

Manang District with an area of 2,246 sq. km and located between $28^{\circ} 27^{\prime} \mathrm{N}$ to $28^{\circ} 54^{\prime} \mathrm{N}$ and $83^{\circ} 49^{\prime}$ $\mathrm{E}$ to $84^{\circ} 34^{\prime} \mathrm{E}$ was selected for the study purpose. It lies in the Tran-Himalayan region characterized by semi-arid cold desert condition like the Tibetan Plateau. The southern part is a deep and narrow U-shaped valley surrounded by the high mountains all around- Annapurna on the south, Choya and Himlung on the north, Manaslu on the east and Muktinath on the west, and receives minimum level of precipitation (NTNC, 2008). The district received about $344 \mathrm{~mm}$ average annual rainfall (at $3420 \mathrm{~m}$ asl) in Manangbhot and $942 \mathrm{~mm}$ (at $2680 \mathrm{~m}$ asl) in Chame, district HQ during 1975-2012 period whereas the yearly temperature in the district varied from $-2.6^{\circ} \mathrm{C}$ (average minimum) in January to $21.5^{\circ} \mathrm{C}$ (average maximum) in July during 1977-2012 in Chame (DHM, 2014). The famous Annapurna Trekking Route passes through this valley. Human settlements are sparsely distributed along the Marsyangdi river, originating from Tilicho Lake (a second highest lake in the world), and flows from the center of the valley. Barren land is the largest land-use category $(68 \%)$ of the district followed by grassland $(22 \%)$, forests $(7 \%)$, shrub-land (2\%) and cultivated land $(<1 \%)$ (LRMP, 1986). The high altitude coniferous forests are found at the upper slope of the valley whereas numerous grasslands are concentrated on the undulating terrains of the northern belt. A. spectabilis can be seen throughout its natural distribution range in the district.

\section{Selection of sampled sites}

Following a reconnaissance survey, three different elevation zones; the lower elevation zone, the middle elevation zone and the upper elevation zone were identified and a sample site was selected within each elevation zone as shown in the location map of the study area (Figure 1). All the sampled sites were located within the prominent natural distribution range of A. spectabilis within the forests land. The lower elevation sampled site $(2,700-3,100 \mathrm{~m})$ was 


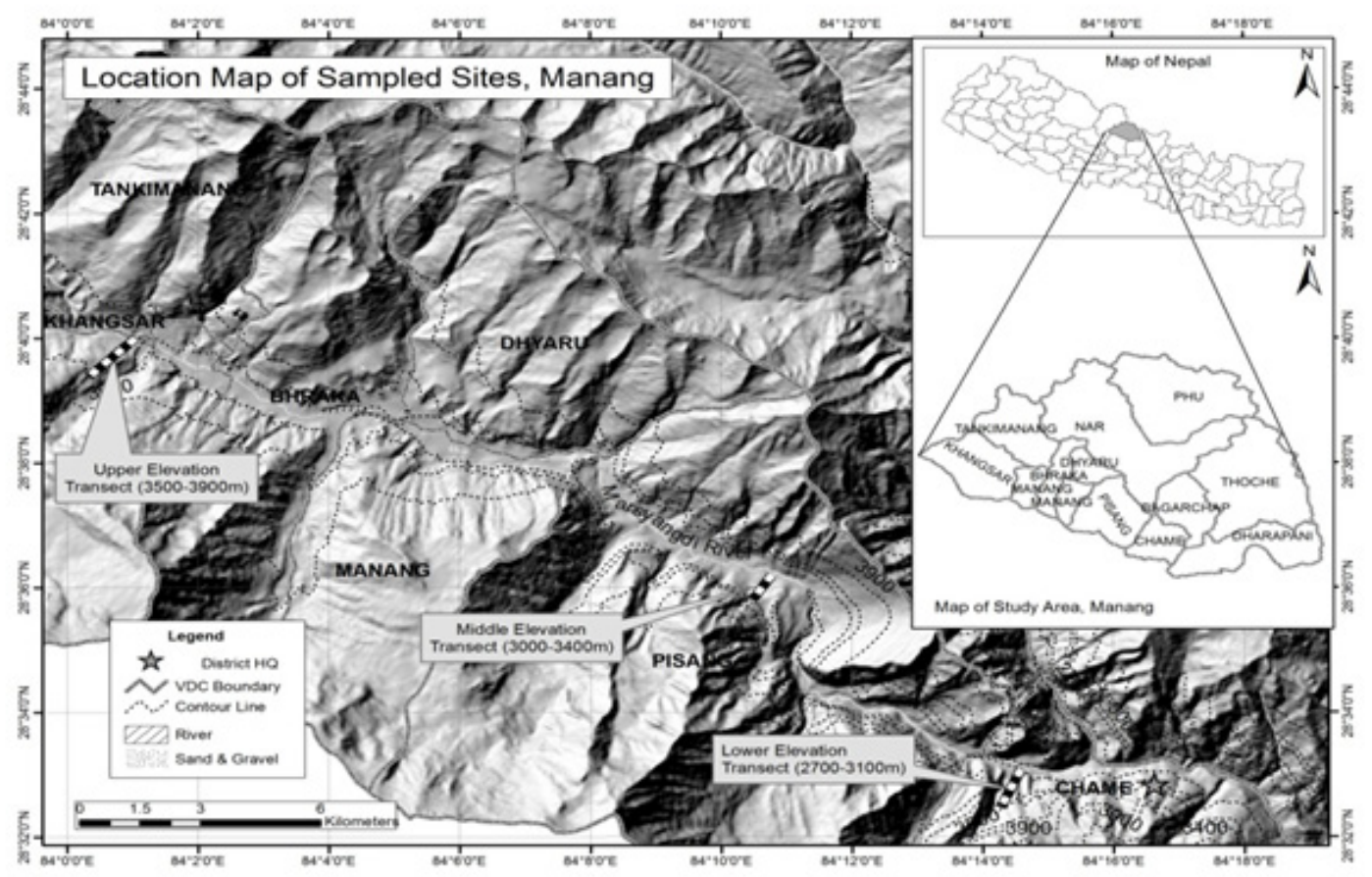

Fig. 1: Location map of the study area and the sample sites

laid out in the Chame Forest of Chame Village Development Committee (VDC), the district headquarters, starting from the bottom of the hill up to the top. Similarly, the middle elevation sampled site $(3,000-3,400 \mathrm{~m})$ was laid out in the Pisang Forest of Pisang VDC, about $15 \mathrm{~km}$ apart from the lower elevation site in the north-west. The upper elevation sampled site (3,500-3,900 m) was laid out in the Khangsar Forest of Khangsar VDC starting from the bottom of the hill up to the treeline. The vegetation sampling was conducted along the transect line in each sampled site during Sept-Oct 2012.

\section{Sampling design, data collection and data analysis}

A $400 \mathrm{~m}$ long transect line along the elevation gradient was established in each sampled site, and divided into four different elevation groups, each with $100 \mathrm{~m}$ length for establishing the sample plots. The locally used trail was followed as the transect line for sample survey, and the sample plots were laid out $10 \mathrm{~m}$ apart from the trail to avoid the direct anthropogenic disturbances. Each transect line in each sampled site was started from the bottom of the hill and ended to the top. It was not possible to create a new transect at the study sites due to steep topography and, therefore, the original plan of five sample plots in each elevation group could not be achieved in some places. The plots located at the terrain with greater than $45^{\circ}$ slopes were avoided for sampling. Table 1 highlights the distribution of sample plots at the three different sites within the study area.

A total of 59 Concentric Circular Sample Plots (CCSPs) of $10 \mathrm{~m}$ radii were established at the three elevation sites wherein the dbh (diameters at breast height) of all the poles (with dbh $>10-25$ $\mathrm{cm}$ ) and the trees of $A$. spectabilis (with dbh $>$ $25 \mathrm{~cm}$ ) were measured for the estimation of basal area. On the other hand, all the saplings (height $>1.3 \mathrm{~m}$ and $\mathrm{dbh}<10 \mathrm{~cm}$ ) were counted within $5 \mathrm{~m}$ radii and the seedlings (height $<1.3 \mathrm{~m}$ )

Table 1: Sampling design and sample distribution

\begin{tabular}{lccccccc}
\hline \multirow{2}{*}{ Sampled sites } & \multirow{2}{*}{$\begin{array}{c}\text { Elevation } \\
\text { range (m) }\end{array}$} & \multirow{2}{*}{$\begin{array}{c}\text { No. of } \\
\text { sample plots }\end{array}$} & \multicolumn{5}{c}{ Distribution of sample plots by elevation groups } \\
\cline { 5 - 8 } & I-100 m & II-100 m & III-100 m & IV-100 m \\
\hline Lower elevation & $2,749-3,145$ & 20 & 4 & 6 & 4 & 6 \\
Middle elevation & $3,015-3,393$ & 19 & 4 & 5 & 4 & 6 \\
Upper elevation & $3,528-3,935$ & 20 & 5 & 4 & 3 & 8 \\
\hline Total & & $\mathbf{5 9}$ & $\mathbf{1 3}$ & $\mathbf{1 5}$ & $\mathbf{1 1}$ & $\mathbf{2 0}$ \\
\hline
\end{tabular}


were counted within $2 \mathrm{~m}$ radii for the purpose of density estimation. Stem numbers of poles and trees were further analyzed by making diameter classes of $10 \mathrm{~cm}$ interval. Per hectare stem density and basal area were calculated for each sampled site and compared with one another. In addition to $A$. spectabilis, all the other woody vegetation within the sample plots were also measured and counted in the same way. Mean, standard error of the mean, ANOVA were used while analyzing the result. Data were analyzed using SPSS-16 and Microsoft Office Excel (2007).

\section{Results and discussion}

\section{Forest structure along the elevation gradient}

There was a significant difference among the elevation zone in stem density distribution ( $p=$ $0.003, \alpha=0.05$, ANOVA). The highest density of woody vegetation was found at the middle elevation site where seedling density reached more than 15,000 per hectare whereas the upper elevation sites hosted just about 5,000 stems/ha (Table 2). However, there was almost a uniform pattern of seedling distribution at the lower and the middle elevation sites and, therefore, did not show significant difference in the sampled mean ( $p=0.78, \alpha=0.05$, ANOVA). The sapling density was found to be the highest $(1,629 \mathrm{stem} / \mathrm{ha})$ in the middle elevation site, and the difference with the other sites is highly significant among the groups $(p=0.004, \alpha=0.05$, ANOVA). The standard errors were found to be within the range of $10 \%$ of the sampled mean for trees, poles and sapling at combined-level while the standard error for the seedling distribution was a little bit higher (nearly $12 \%$ ) (Table 2). There was a decreasing trend in the basal areas of the average woody plants as well as A. spectabilis with the increase in elevation. The proportion of seedling density varied from about
$84 \%$ in the upper elevation to $89 \%$ at the middle elevation whereas the proportion of tree density was just about $0.7 \%$ at the middle elevation to $1.7 \%$ at the lower elevation.

The tree density and the basal area varied between the sites as well as between the regions depending upon the geographical and climatic conditions in the area. The currently recorded tree density at the upper site was found to be both higher as well as lower than the one recorded in some other studies in the Himalayan region. Gaire et al. (2010) found the average tree density of $734 \mathrm{stem} / \mathrm{ha}$ and the average basal area of $20.56 \mathrm{~m}^{2} / \mathrm{ha}$ in the treeline ecotone of Langtang National Park. In another study, Bhuju et al. (2010) recorded a density of $445 \mathrm{stems} / \mathrm{ha}$ and total basal area of $11.2 \mathrm{~m}^{2} / \mathrm{ha}$ from the treeline region while a density of 1,034 stems/ha and a basal area of $18.6 \mathrm{~m}^{2} /$ ha from the treeline region of the Sagarmatha National Park. In a study conducted in Dolpa region, Kunwar and Sharma (2004) found the total stand density of 2100 trees/ha $(\mathrm{dbh}>10 \mathrm{~cm})$ and the basal area of $90 \mathrm{~m}^{2} /$ ha in Amaldapani community forests while the stand density of 2,090 trees/ha (dbh $>10 \mathrm{~cm}$ ) and the basal area of $152 \mathrm{~m}^{2} /$ ha in Juphal community forests. Shaheen et al. (2012) found the average tree density of $151 \mathrm{stems} / \mathrm{ha}$ and the basal area of $68.8 \mathrm{~m}^{2} /$ ha in a western Himalayan moist temperate forest in Kashmir (Pakistan). Similarly, Sharma et al. (2014) found the mean stand density of 613 stems/ha (552-710 stems/ ha) and the mean basal area of $84.37 \mathrm{~m}^{2} / \mathrm{ha}$ $\left(75.18-92.07 \mathrm{~m}^{2} / \mathrm{ha}\right.$ ) from an assessment of forest structure and woody plant regeneration on the ridge at the Upper Bhagirathi basin in Garhwal Himalaya (India). They also found slightly an inversely J-shaped dbh class distribution with gaps in some dbh classes.

The tree species in the forests of Manang district

Table 2: Summary statistics of woody vegetation and $\boldsymbol{A}$. spectabilis by elevation sites

\begin{tabular}{llrrrrrr}
\hline $\begin{array}{l}\text { Vegetation } \\
\text { types }\end{array}$ & $\begin{array}{c}\text { Elevation } \\
\text { sites }\end{array}$ & \multicolumn{6}{c}{ Parameters } \\
\cline { 3 - 8 } Soedlings/ha & Saplings/ha & Poles/ha & Trees/ha & Stems/ha & BA(m $/ \mathbf{h a})$ \\
\hline species & Lower & 14,013 & 1,032 & 135 & 140 & 15,320 & 35.8 \\
& Middle & 15,044 & 1,629 & 272 & 179 & 17,124 & 27.2 \\
& Upper & 5,056 & 586 & 104 & 100 & 5,846 & 22.6 \\
& Average & $\mathbf{1 1 , 3 0 8}$ & $\mathbf{1 , 0 7 3}$ & $\mathbf{1 6 8}$ & $\mathbf{1 3 9}$ & $\mathbf{1 2 , 6 8 9}$ & $\mathbf{2 8 . 5}$ \\
A. spectabilitis & Lower & 2,070 & 242 & 25 & 40 & 2,377 & 15.9 \\
& Middle & 8,255 & 784 & 139 & 60 & 9,239 & 8.5 \\
& Upper & 1,154 & 166 & 40 & 13 & 1,373 & 1.4 \\
& Average & $\mathbf{3 , 7 5 1}$ & $\mathbf{3 9 1}$ & $\mathbf{6 7}$ & $\mathbf{3 7}$ & $\mathbf{4 , 2 4 6}$ & $\mathbf{8 . 6}$ \\
\hline
\end{tabular}


demonstrated continuous regeneration at all elevations with inversely J-shaped size class distribution (Figure 2d), despite some gaps in some diameter classes at individual elevation sites (Figure 2a and Figure 2c). An inversely J-shaped stem distribution showed that the forests at the lower elevation possessed both the recent regeneration as well as the very old growth stem $(\mathrm{dbh}>100 \mathrm{~cm})$. The forests at the middle elevation lacks the large-sized trees $(\mathrm{dbh}>80 \mathrm{~cm})$. The size class structure (age, dbh and height) indicates the regeneration condition in the forest (Wangda and Ohswa, 2006; Lv and Zhang, 2012; Gaire et al., 2011, 2014). Based on size class structure, the woody species can demonstrate three types of regeneration: unimodal, sporadic, and inversely J-shaped (Wangda and Ohshwa 2006). Gaire et al. (2010) observed an inversely J-shaped size class distribution in the treeline ecotone of Langtang National Park. Maren et al. (2015) found almost similar regeneration condition based on the dbh class distribution (inversely J-shaped) of Pinus wallichiana and Juniperus indica in the forests situated on the north and the south-facing slopes in the Manang Valley. Similarly, Wangda and Ohshwa (2006) found continuous to sporadic regeneration of different tree species along the altitudinal gradient in a dry valley slope of Bhutan
Himalaya.

\section{Population structure of $A$. spectabilis}

The densities of $A$. spectabilis as well as the other woody plants were found to be the highest at the middle elevation while their basal areas were found to be the highest at the lower elevation and were found to have decreased with the increase in elevation (Table 2). The matured trees were found to have contributed for the highest basal area at the lower elevation as the average density was less than that at the middle elevation. Such decreasing trends in the density and the basal area were also observed at the other sites of the Nepal Himalaya (Shrestha et al., 2007; Bhuju et al., 2010). In another study conducted along the altitudinal gradient in a dry valley slope of the Bhutan Himalaya, Wangda and Ohshwa (2006) found the basal area in the range of 15.2-145.6 $\mathrm{m}^{2} /$ ha with the highest total basal area in Abies densa-Tsuga dumosa dominated forest at the middle elevation.

The average seedling density of $A$. spectabilis was about 3,751 plants/ha (about one third of total seedling) in Manang forest with the lowest density status at the upper elevation $(1,154 / \mathrm{ha}$.) and the highest at the middle elevation $(8,255$ /

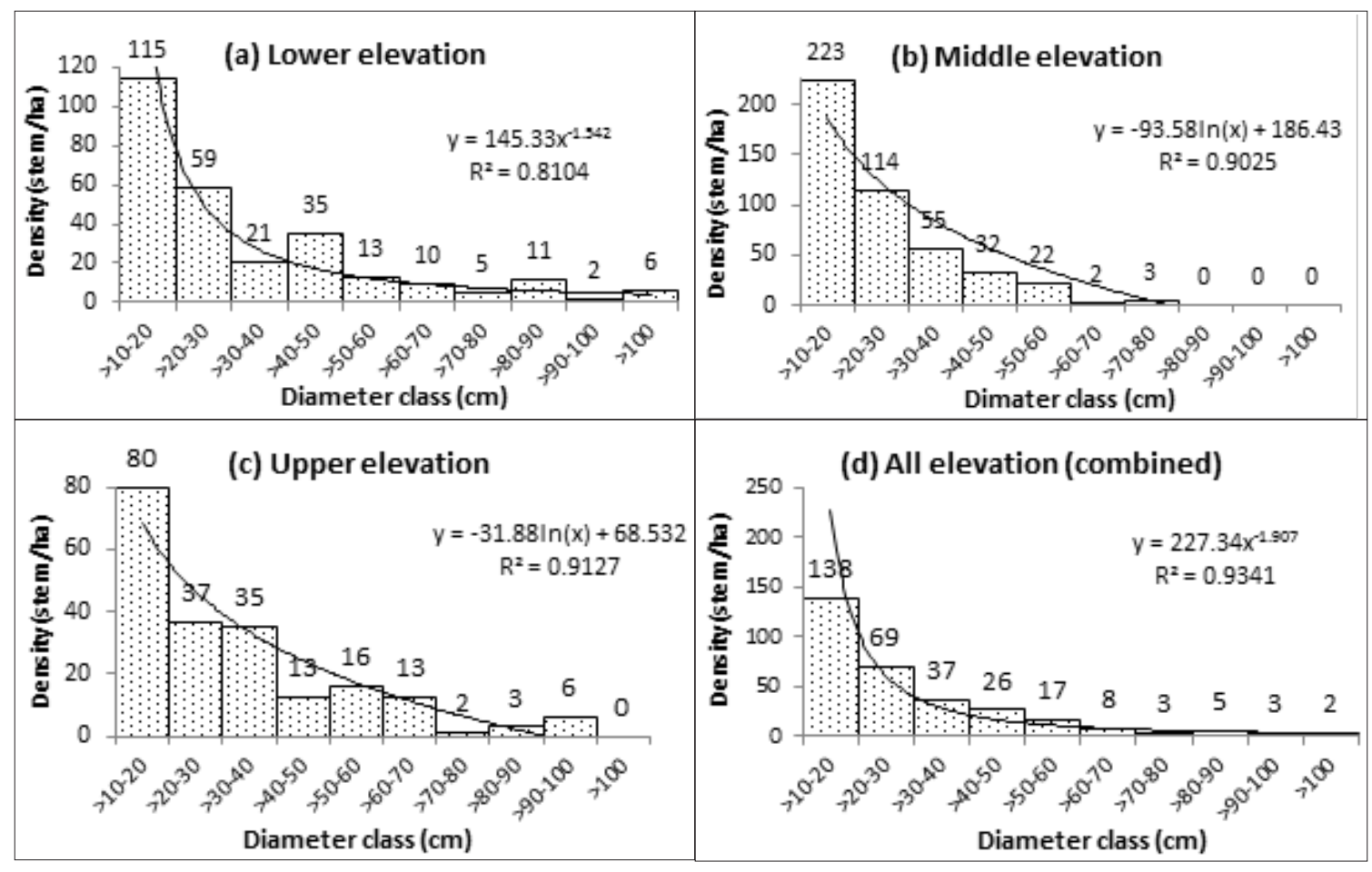

Fig. 2: Stem density distribution by diameter classes at different elevation sites 
ha) (see Table 2). The stems (saplings, poles and trees) of $A$. spectabilis were densely present at the middle elevation (Figure 5) like the total woody vegetation structure (Table 2). The statistics shows that the average densities of all stem categories are significantly different among the elevation sites. The SEs of $A$. spectabilis distribution were found to be higher $(>10 \%)$ than the SEs of total woody species at combined level indicating higher variation of sample mean among the plots. Forest survey in Nepal generally follows the 10\% error margin at 95\% CI (DFRS, 2014a,b).

The tree, sapling and seedling density of $A$. spectabilis recorded in this study is comparable with the density in the other parts of the Nepal Himalaya. A. spectabilis sapling density was 648 stems/ha in Manaslu Conservation Area (Sujakhu et al., 2013) and the sapling density declined with increase in elevation. In the same area, $A$. spectabilis tree density is $412 \mathrm{stem} / \mathrm{ha}$ and basal area is $11.64 \mathrm{~m}^{2} / \mathrm{ha}$. The total tree density was more in the mixed forest $(2,054$ stems/ha) than in the pure forest $(1,707$ stems/ha) (Sujakhu et al., 2013). Kunwar and Sharma (2004) found out A. spectabilis density ranged from 250 to 510 trees/ha in Amaldapani and Juphal community forests of Dolpa District. They found an inversely J-shaped dbh class distribution in both the sites. The average trees, saplings and seedlings densities of $A$. spectabilis in the treeline ecotone of Langtang National Park were 236, 255 and 350 stems/ha respectively (Gaire et al., 2011). The per hectare tree stem density of $A$. spectabilis in the treeline ecotone of Sagarmatha National Park was found to be 120 and 359 respectively (Bhuju et al., 2010). In the treeline ecotone of the Rolwaling Valley, Schickhoff et al. (2015) also found the highest seedling density of all the species including $A$. spectabilis at the middle elevation of the north-east slope but seedling density decreased with the decrease in elevation on the north-west slope. The variation in the densities along the elevation gradient might be the result of the variations in the soil nutrients and other abiotic as well as climatic factors.

The population structure of $A$. spectabilis was quite different (Figure 3) than the total woody vegetation in each elevation site (Figure 2). However, the structural composition at combined level looks uniform (Figure 2d and Figure 3d). The combine DBH class distribution shows nearly an inversely J-shaped distribution indicating sustainable regeneration of $A$. spectabilis along elevation bands. Considering the individual bands, gaps in some diameter class was observed which might be due to some anthropogenic disturbances in the past or episodic regeneration. This structure indicates the characteristics of normal forests in the study area. However, a huge gap between seedling and sapling distribution was found mainly due to the class interval of stem diameter during the measurement period. Ghimire and Lekhak (2007) found absence of higher girth class of $A$. spectabilis trees (above $45 \mathrm{~cm}$ diameter) in Pisang Annapurna region but present study recorded the diameter greater

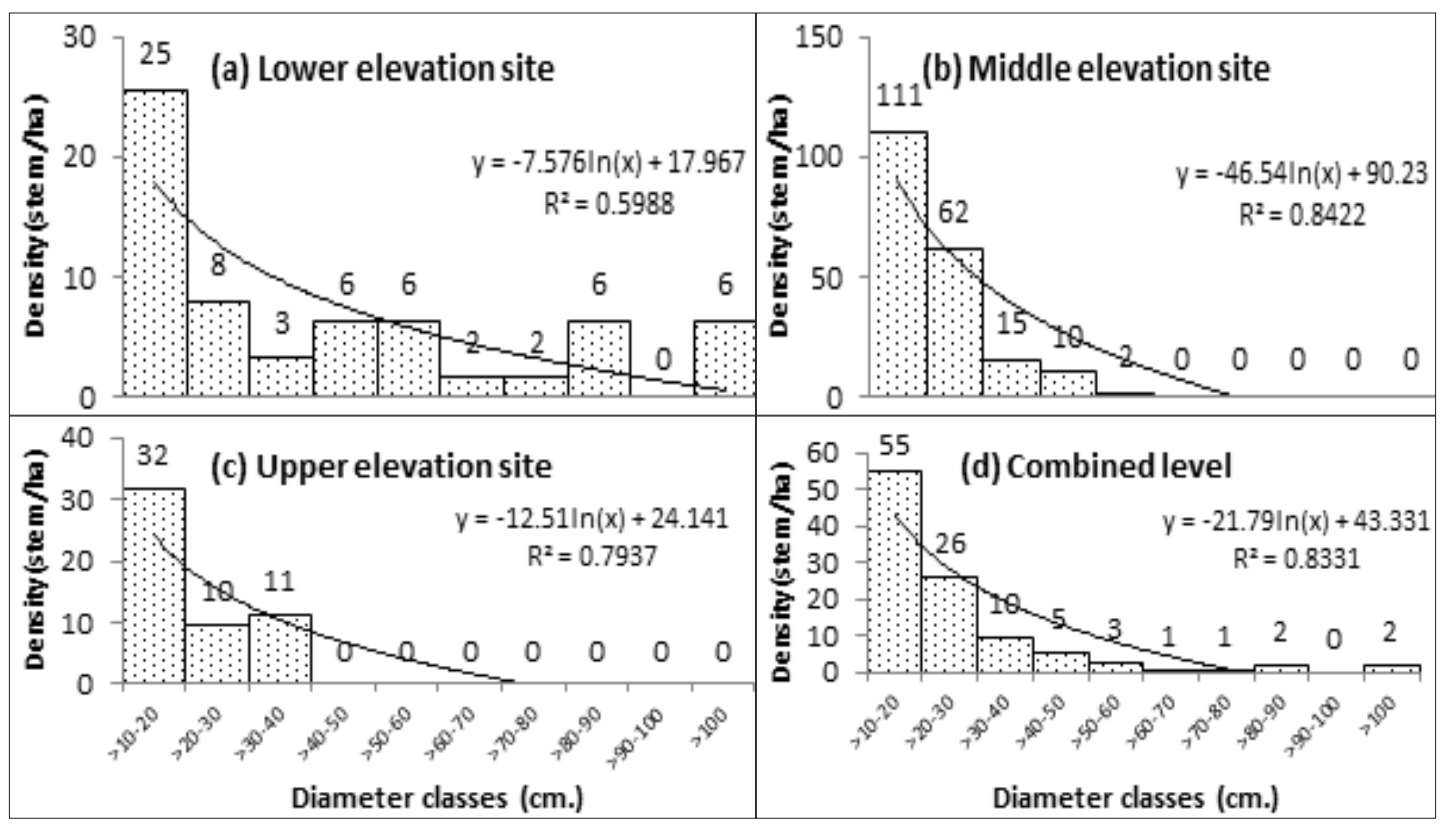

Fig. 3: Structural composition of $\boldsymbol{A}$. spectabilis by elevation sites 
than $100 \mathrm{~cm}$ for same species. Gaire et al. (2010) found inversely $\mathrm{J}$-shaped to bell shaped diameter class distribution of $A$. spectabilis in the treeline ecotone of Langtang National Park while an inversely J-shaped to bimodal bell-shaped distribution in the treeline ecotone of Manaslu Conservation Area (Gaire et al., 2014). Similarly, from a study of high altitude forest, Bhuju et al. (2010) observed bell-shaped diameter class distribution of $A$. spectabilis at the treeline (Pangboche) and inversely J-shaped pattern at the treeline (Debuche) of Sagarmatha National Park. Lv and Zhang (2012) found inversely J-shaped to uni-multimodal bell-shaped dbh distribution of A. spectabilis along the elevation gradient in the Tibetan side of Mt. Everest.

A noticeable variation in stem distribution pattern was found between the elevation gradients in the study area (Figure 4). The large number of seedlings and saplings of $A$. spectabilis found at the upper elevation including the treeline ecotone of the study area indicates its stand densification as observed by Gaire et al., (2011 and 2014) and Chhetri and Cairns (2015) at the other treeline ecotones of Nepal. The results show that A. spectabilis is responding to the recent environmental change and revealing its potential for upward migration in the future.

There was a great variation in the proportion of A. spectabilis as compared to the total number of stem (including those of the other woody vegetation too) within the same elevation sites (Figure 4). However, such proportions of $A$. spectabilis were found to be the highest at the middle elevation. More than half (about 55\%) of the total seedlings at the middle elevation was occupied by $A$. spectabilis alone. On the contrary, the lower elevation site was characterized by lesser proportions of $A$. spectabilis seedlings (14.8\%) and saplings (23.5\%) (Figure 4).

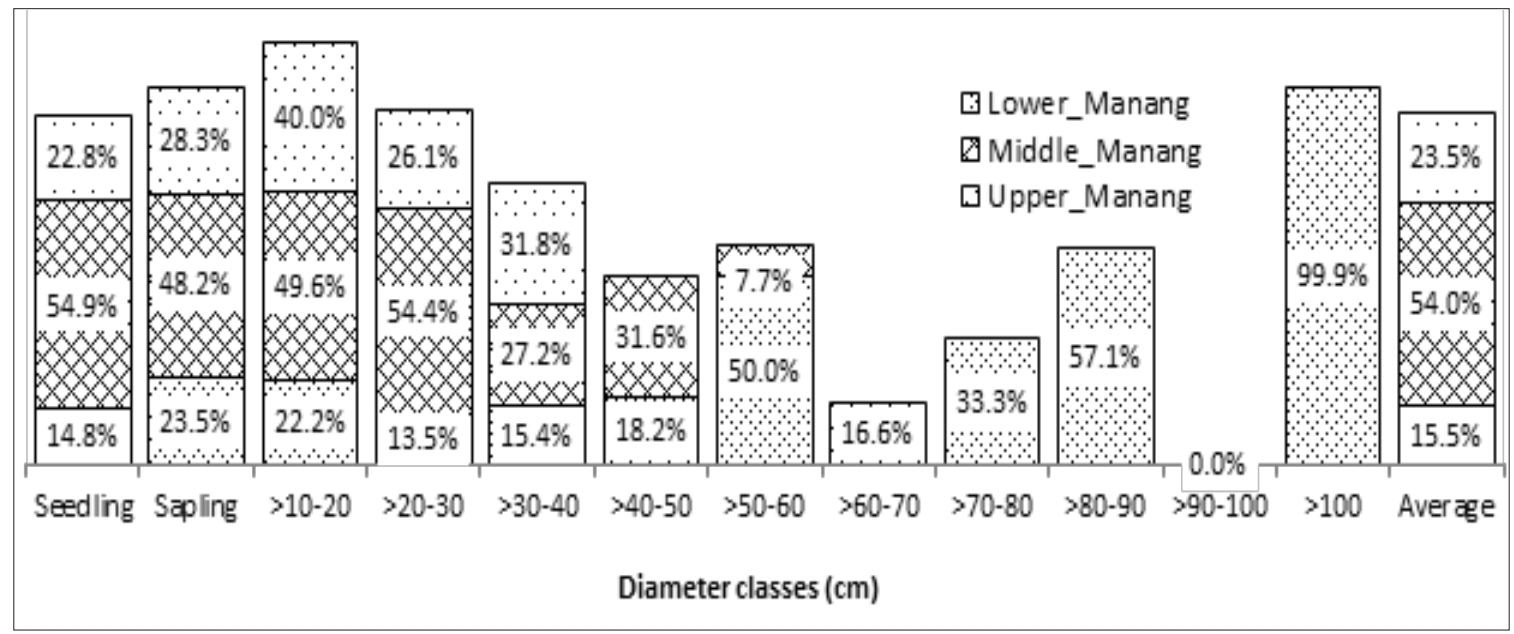

Fig. 4: Proportion of $A$. spectabilis with respect to the total stem in the study area

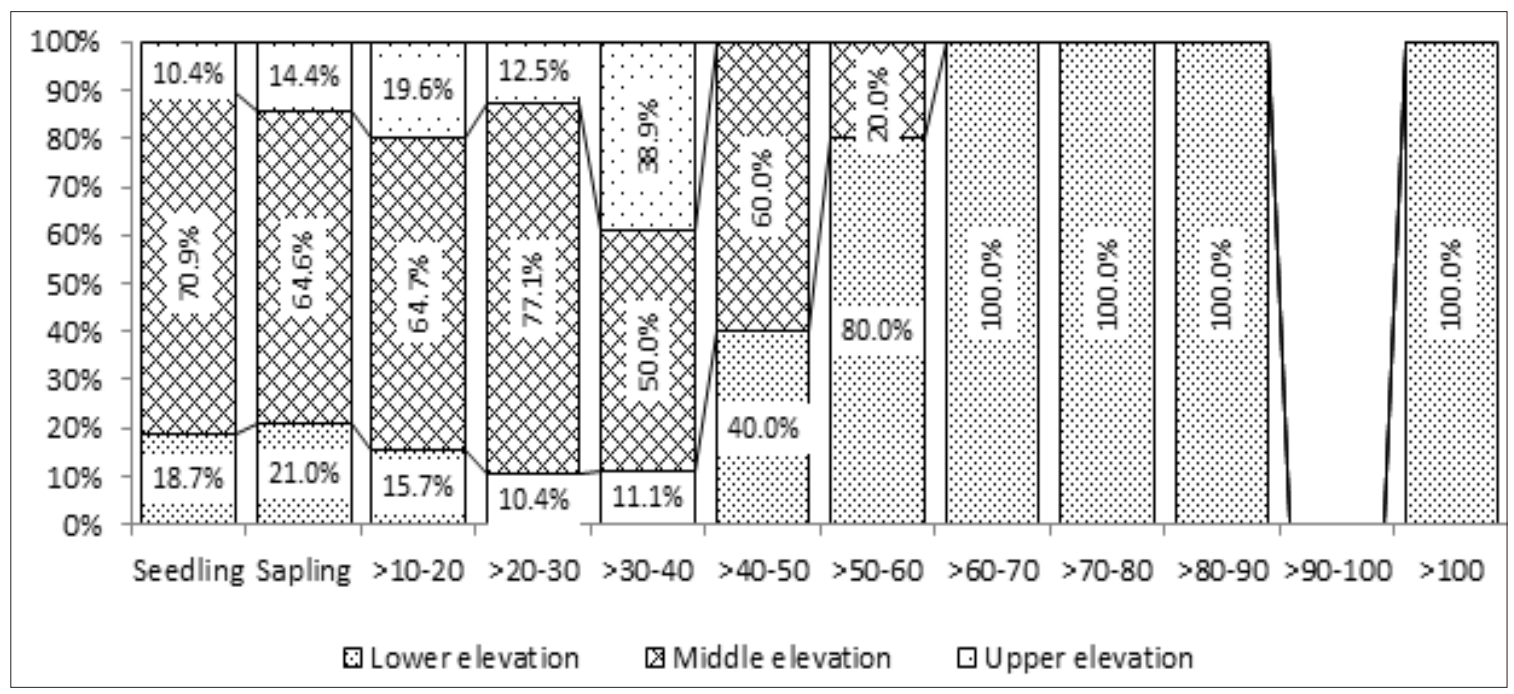

Fig. 5: Stem distribution of $A$. spectabilis by elevation sites in the study area 
Out of the total stem distribution, more than two third of the A. spectabilis seedlings were found at the middle elevation alone, and only about $10 \%$ was observed at the upper elevation (Figure 5). The trend was almost similar in the case of saplings and pole-sized stems. Even more than half of the total tree stems were found at the same elevation. The middle and the upper elevation sites were lacked of large sized trees $(>70$ $\mathrm{cm})$. According to the concepts of ecological amplitude, environmental condition of the middle distribution range of a species would be generally favorable for the growth (Fritts, 1976). Therefore, higher values of plant density might be associated with this.

The comparisons of the proportions of seedlings, saplings and trees including all size class along the elevation-gradient revealed almost synchronous recent regeneration of $A$. spectabilis despite a minor difference in the recruitment pattern in the past history. Minor difference in the regeneration pattern might be due to the fluctuations in soil nutrients and other abiotic parameters along elevation gradient (Shrestha et al., 2007). Lv and Zhang (2012), however, found asynchronous recruitment history of A. spectabilis along an altitudinal gradient $(3,410-3,920 \mathrm{~m})$ in the Tibetan side of Mt. Everest region. That study also found high tree $(>10 \mathrm{~cm}$ dbh) density at the middle elevation as compared to the upper and lower elevations with density ranging from $344-1,106$ stems per ha. On the contrary, Lv and Zhang (2012) found good regeneration of $A$. spectabilis at the treeline area, but did not find its regeneration at the middle elevation $(3,520-3,700 \mathrm{~m})$. At the treeline ecotone of Mansalu Conservation Area, the regeneration of $A$. spectabilis is positively correlated with the precipitation of August and monthly maximum temperature of most of the months of the current year (Gaire et al., 2014), indicating low temperature limits for the recruitment of this species in cold environment like treeline. Lv and Zhang (2012) also reported that recruitment of fir trees at the treeline was sensitive to summer (June-September) temperatures, but that was mainly controlled by episodic disturbances at lower altitudes. The high moisture in spring and summer months also has significant role for fir recruitment in the treeline area of Tibetan side of Mt. Everest region (Lv and Zhang, 2012). The climatic factors affecting upon the recent regeneration of $A$. spectabilis along the elevation gradient including the treeline area of the present study area need to be further studied. However, the recent synchronous recruitment along the elevation gradient shows wider sensitivity of $A$. spectabilis towards the recent climatic change, especially temperature change, in the area.

\section{Stem basal area of $A$. spectabilis}

The per hectare basal area was found to be the highest $\left(15.9 \mathrm{~m}^{2} / \mathrm{ha}\right)$ at the lower elevation as compared to the other two elevation sites

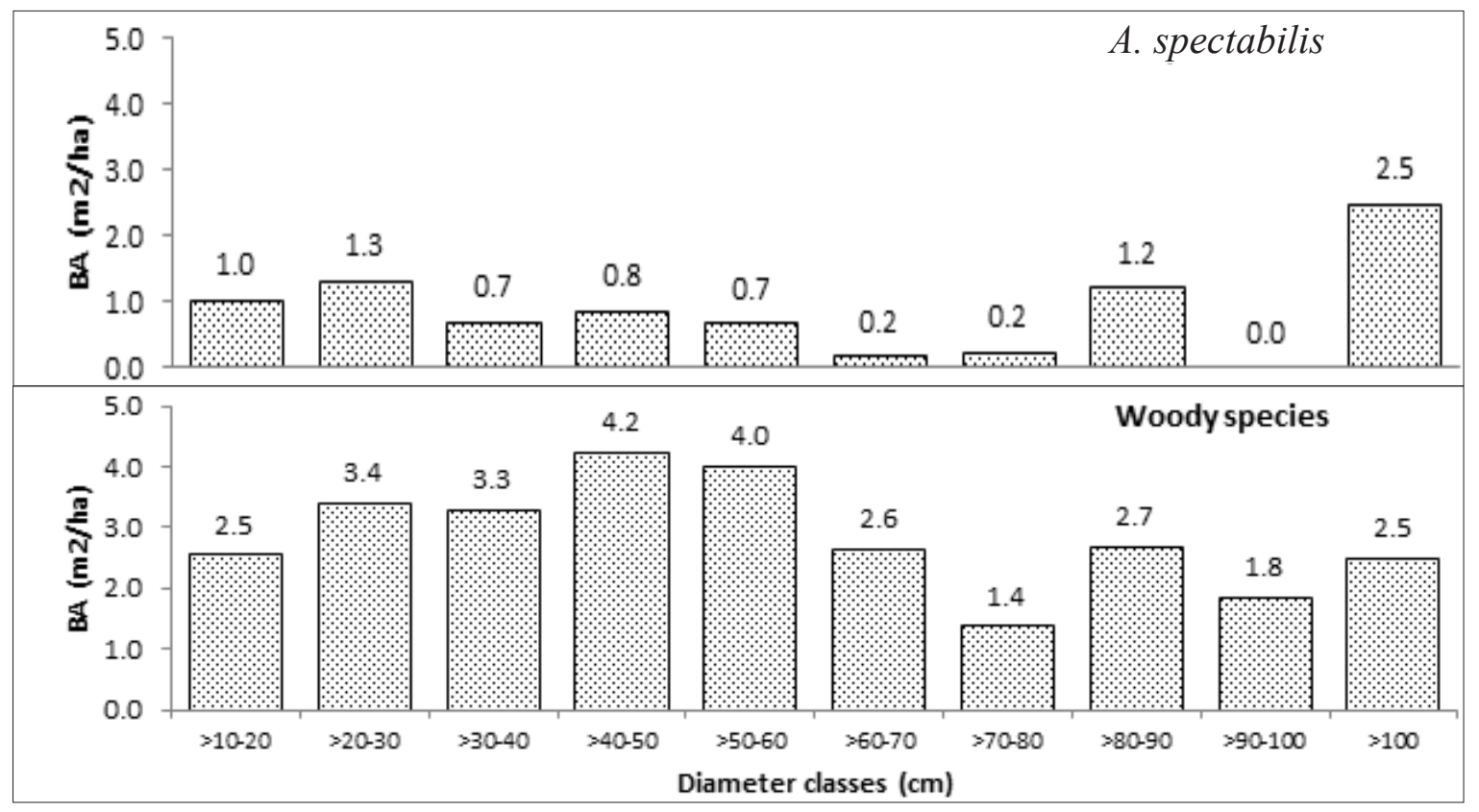

Fig. 6: Per hectare basal area of all woody vegetation including $A$. spectabilis by diameter classes 
with standard error (SE) of $5.6 \mathrm{~m}^{2} /$ ha (Table 2 ). The distribution of large-sized trees at the lower elevation site had caused for the high per hectare basal area while the number of trees and pole-sized stems were lowest at the Upper Manang which in turn had caused for the highly significant differences in the mean basal areas of the trees and the poles among the elevation sites (Table 2). The error margins of the per hectare basal areas at combined level was found to be quite high $(>20 \%)$ as compared to the per hectare stem density $(<10 \%)$. Absence of trees and pole sized stems in some sampled plots as well as sized trees at the middle and the upper elevation sites. The high stem density may hinder the growth of large-sized trees at the middle elevation while the harsh climatic and topographic conditions at the upper elevation sites may not be suitable for the natural distribution of the species. However, the presence of only small-sized trees with good regeneration of $A$. spectabilis at the upper site shows its potential for the upward migration with environmental change including climate change in the future.

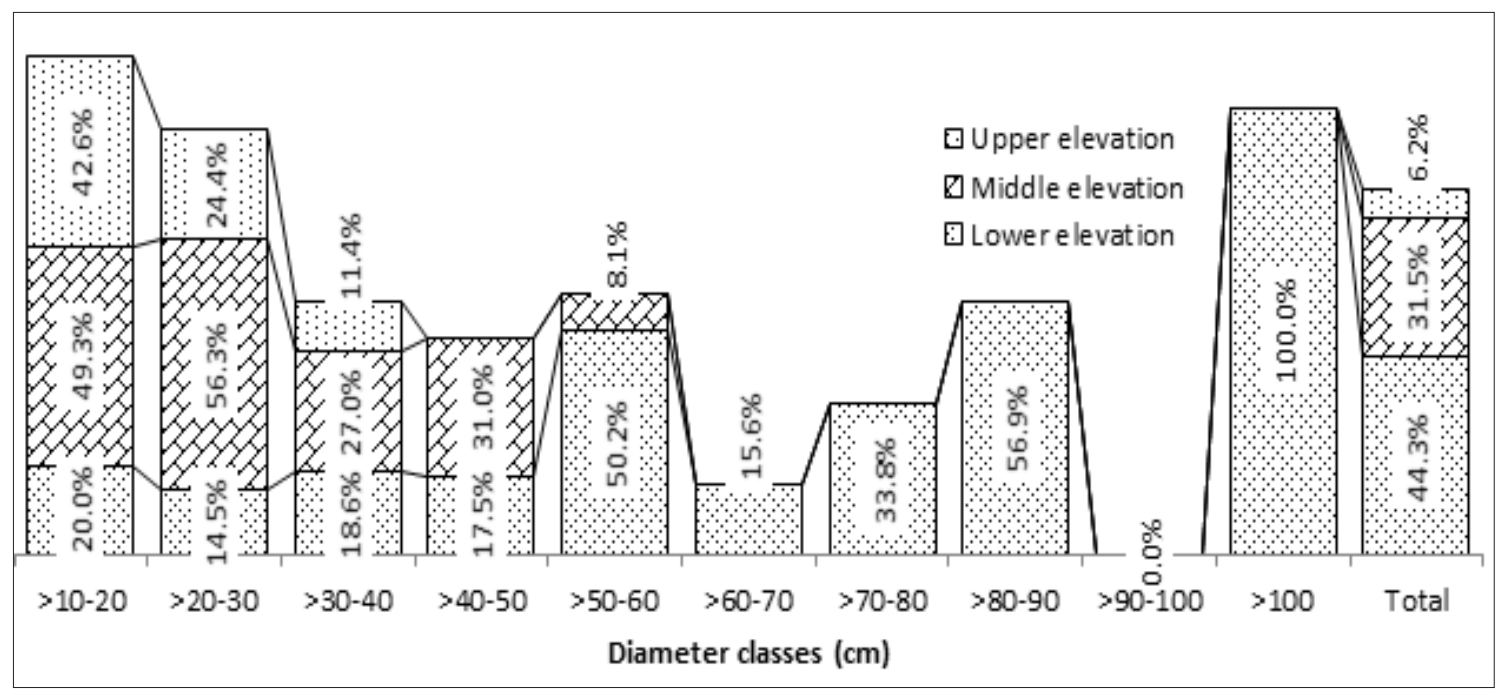

Fig. 7: Basal area proportion of $A$. spectabilis compared to total woody vegetation

great variation in plot to plot distribution of $A$. spectabilis might have caused the high level of error margin in the basal area estimation.

The results showed that A. spectabilis shared about $30 \%$ of the total basal area, of all the three sites, ranging from $44.3 \%$ at the lower elevation to $6.2 \%$ at the upper elevation (Figure 7 ).

\section{Conclusion}

The Himalayan forest of Manang District contains a good population of $A$. spectabilis with high variation in its occurrence along the elevation gradient. A. spectabilis is found at the altitude of $2,700-4,000 \mathrm{~m}$, i.e., up to the treeline ecotone. The high density of all stem categories of the species was observed at the middle elevation sites though its stem basal area was found to be significantly higher at the upper part of Lower Manang. The stem distribution of this species at combinedlevel at the three elevations sites indicates the characteristics of normal (sustainable) forest in the study area although there is a lack of large-

\section{Acknowledgements}

This research was accomplished under a $\mathrm{PhD}$ research scholarship funded by the Communitybased Forest Management in the Himalayas (ComForM III) Project, a joint initiative of the University of Copenhagen (Denmark), Institute of Forestry, Pokhara and the Department of Forest Research and Survey, Kathmandu. We are thankful to Mr. Rabindra Maharjan, District Forest Officer, Dolakha, for his support in map preparation as well as in the fieldwork. We acknowledge Annapurna Conservation Area Project (ACAP, Nepal) for providing permission to carry out the fieldwork.

\section{References}

Bhattacharyya, A., Lamarche, V. C. J. and Hughes, M. K. 1992. Tree-ring chronologies from Nepal. Tree Ring Bulletin 52: 59-66.

Bhuju, D. R., Carrer, M., Gaire, N. P. Soraruf, L. Riondato, R. Salerno F. and Maharjan, S. R. 
2010. Dendroecological study of high altitude forest in Sagarmatha National Park, Nepal. In Contemporary Research in Sagarmatha (Mt. Everest) Region, Nepal (eds) Jha, P. K. and Khanal I. P. Nepal Academy of Science and Technology, Khumaltar, Lalitpur, 119-130.

Bradley, R. S. and Jones, P. D. 1993. Little Ice Age' summer temperature variations: their nature and relevance to recent global warming trends. Holocene 3: 367-376.

Camarero, J. J. and Gutiérrez, E. 2004. Pace and pattern of recent treeline dynamics: response of ecotones to climatic variability in the Spanish Pyrenees. Climatic Change 63: 181200.

Chen, I. C., Hill, J. K., Ohlemüller, R., Roy, D. B. and Thomas, C. D. 2011. Rapid range shifts of species associated with high-levels of climate warming. Science 333: 1024-1026.

Chhetri, P. K. and Cairns, D. M. 2015. Contemporary and historic population structure of Abies spectabilis at treeline in Barun Valley, Eastern Nepal Himalaya. Journal of Mountain Science 12 (3): 558570.

DFRS. 2014a. Terai Forests of Nepal. Forest Resource Assessment Nepal Project/ Department of Forest Research and Survey, Kathmandu, Nepal.

DFRS. 2014b. Churia Forests of Nepal. Forest Resource Assessment Nepal Project/ Department of Forest Research and Survey, Kathmandu, Nepal.

DHM, 2014. Meteorological data of Nepal. Department of Hydrology and Meteorology, Kathmandu, Nepal.

Fritts, H. C. 1976. Tree Rings and Climate. Academic Press. London, UK.

Gaire, N. P., Bhuju, D. R., Koirala, M. and Borgaonkar, H. P. 2014. Treeline dynamics with climate change at Central Nepal Himalaya. Climate of the Past 10: 12771290, (www.clim-past.net/10/1277/2014/ doi: 10.5194/cp-10-1277-2014).

Gaire, N. P., Dhakal, Y. R., Lekhak, H. C., Bhuju, D. R. and Shah, S. K. 2011. Dynamics of Abies spectabilis in relation to climate change at the treeline ecotone in Langtang National Park. Nepal Journal of Science and Technology 12: 220-229.

Gaire, N. P., Dhakal, Y. R., Lekhak, H. C., Bhuju, D. R. and Shah, S. K. 2010. Vegetation dynamics in treeline ecotone of Langtang National Park, Central Nepal. Nepal Journal of Science and Technology 11: 107-114.

Ghimire, B. K. and Lekhak, H. D. 2007. Regeneration of Abies spectabilis (D. Don Mirb.) in subalpine forest of Upper Manang, North-central Nepal. In Local Effects of Global Changes in the Himalayas: Manang, Nepal (eds) Chaudhary, R. P., Aase, T. H., Vetaas, O. and Subedi, B. P., Tribhuvan University, Nepal; University of Bergen, Norway, 139-149.

Ghimire, S. K., Sapkota, I. B., Oli, B. R., and Prajuli, R. R. 2008. Non-timber Forest Products of Nepal Himalaya, WWF Nepal, Kathmandu, Nepal.

Gottfried, M., Pauli, H., Futschik, A., Akhalkatsi, M., Baran cok, P., Alonso, J. L. B., Coldea, G., Dick, J., Erschbamer, B., Calzado, M. R. F., Kazakis, G., Kraj ci, J., Larsson, P., Mallaun, M., Michelsen, O., Moiseev, D., Moiseev, P., Molau, U., Merzouki, A., Nagy, L., Nakhutsrishvili, G., Pedersen, B., Pelino, G., Puscas, M., Rossi, G., Stanisci, A., Theurillat, J. P., Tomaselli, M., Villar, L., Vittoz, P., Vogiatzakis, I. and Grabherr, G. 2012. Continent-wide response of mountain vegetation to climate change. Nature Climate Change 2: 111-115.

ICIMOD. 2010. The Glaciers of the Hindu Kush-Himalayan Region: A summary of the science regarding glacier melt/retreat in the Himalayan, Hindu Kush, Karakoram, Pamir, and Tien Shan mountain ranges. International Centre for Integrated Mountain Developemnt, Khumaltar, Lalitpur, Nepal.

IPCC. 2014: Summary for policymakers. In Climate Change 2014: Impacts, Adaptation, and Vulnerability. Part A: Global and Sectoral Aspects. Contribution of Working Group II to the Fifth Assessment Report of the Intergovernmental Panel on Climate Change (eds) Field, C. B., Barros, V. R. Dokken, D. J., Mach, K. J., Mastrandrea, M. D., Bilir, T. E., Chatterjee, M., Ebi, K. L., Estrada, Y. 
O., Genova, R. C., Girma, B., Kissel, E. S., Levy, A. N., MacCracken, S., Mastrandrea, P. R. and White, L. L. Cambridge University Press, Cambridge, United Kingdom and New York, NY, USA, 1-32.

Jackson, J. K. 1994. Manual of Afforestation in Nepal. 2nd edition. Forest Research and Survey Centre, Kathmandu, Nepal.

Kullman, L. 1998. Tree limits and montane forests in the Swedish Scandes: sensitive biomonitors of climate change and variability. Ambio 27: 312-321.

Kunwar, R. M. and Sharma, S. P. 2004. Quantitative analysis of tree species in two community forests of Dolpa District, Midwest Nepal. Himalayan Journal of Sciences 2 (3): 23-28.

LRMP. 1986. Land System Report, Land Resource Mapping Project, Nepal. Kenting Earth Science, Canada.

Lv, L. X. and Zhang, Q. B. 2012. Asynchronous recruitment history of Abies spectabilis along an altitudinal gradient in the Mt. Everest region. Journal of Plant Ecology 5: 147-156.

Maren, I. E., Karki, S., Prajapati, C., Yadav, R. K. and Shrestha. B. B. 2015. Facing north or south: Does slope aspect impact forest stand characteristics and soil properties in a semiarid trans-Himalayan valley? Journal of Arid Environments 121: 112-123.

GoN/MoE. 2010. National Adaptation Programme of Action (NAPA). Ministry of Environment, Government of Nepal, Kathmandu, Nepal.

Moktan, M. R., Gratzer, G., Richards, W. H., Rai, T. B. and Dukpa, D. 2009. Regeneration and structure of mixed conifer forests under single tree harvest management in the Western Bhutan Himalayas. Forest Ecology and Management 258: 243-255.

HMGN/MFSC. 2002. National Biodiversity Strategy Nepal. Ministry of Forests and Soil Conservation, His Majesty Government of Nepal, Kathmandu, Nepal.

NTNC. 2008. Sustainable Development Plan of Manang, 2008-2013. National Trust for Nature Conservation, United Nations
Environment Program and Government of Nepal, Kathmandu, Nepal.

Parolo, G. and Rossi, G. 2008. Upward migration of vascular plants following a climate warming trend in the Alps. Basic Applied Ecology 9: 100-107.

Root, T. L., Price, J. T., Hall, K. R., Schneider, S. H., Rosenzweigk, C. and Pounds, J. A. 2003. Finger prints of global warming on wild animals and plants. Nature 421: 57-60.

Sano, M., Furuta, F., Kobayashi, O. and Sweda, T. 2005. Temperature variations since the mid 18th century for Western Nepal, as reconstructed from tree-ring width and density of Abies spectabilis. Dendrochronologia 23: 83-92.

Schweingruber, F. H. 1996. Tree Rings and Environment: Dendroecology. Birmensdorf, Swiss Federal Institute for Forest, Snow and Landscape Research. Berne, Stuttgart, Vienna, Austria.

Schickhoff, U., Bobrowski, M. Böhner, J., Bürzle, B., Chaudhary, R. P., Gerlitz, L., Heyken, H., Lange, J., Müller, M., Scholten, T., Schwab, N. and Wedegärtner, R. 2015. Do Himalayan treelines respond to recent climate change? An evaluation of sensitivity indicators. Earth System Dynamics 6: 245-265.

Shaheen, H., Ullah, Z., Khan, S. M. and Harper, D. M. 2012. Species composition and community structure of western Himalayan moist temperate forests in Kashmir. Forest Ecology and Management 278: 138-145.

Sharma, C. M., Mishra, A. K., Prakash, O., Dimri, S. and Baluni, P. 2014. Assessment of forest structure and woody plant regeneration on ridge tops at Upper Bhagirathi basin in Garhwal Himalaya. Tropical Plant Research 1 (3): 62-71.

Shrestha, A. B., Wake, C. P., Mayewski, P. A. and Dibb, J. E. 1999. Maximum temperature trend in the Himalaya and its vicinity: An analysis based on temperature records from Nepal for period 1971-94. Journal of Climate 12: 2775-2787.

Shrestha, B. B., Ghimire, B., Lekhak, H. D., and Jha, P. K. 2007. Regeneration of treeline Birch (Betula utilis D. Don) forest in Trans- 
Himalayan dry valley in Central Nepal. Mountain Research and Development 27: 250-258.

Stainton, J. D. A. 1972. Forests of Nepal. The Camelot Press Limited, Southampton, London, UK.

Sujakhu, H., Gosai, K. R. and Karmacharya, S. B. 2013. Forest structure and regeneration pattern of Betula utilis D. Don in Manaslu Conservation Area, Nepal. ECOPRINT 20: 107-113.

Suzuki, E. 1990. Dendrochronology in coniferous forests around Lake Rara, West Nepal. Botanical Magazine Tokyo 103: 297-312.

Wangda, P. and Ohsawa, M. 2006. Structure and regeneration dynamics of dominant tree species along altitudinal gradient in a dry valley slopes of the Bhutan Himalaya. Forest Ecology and Management 230: 136-150.

Webb, L. B., Whetton, P. H., Bhend, J., Darbyshire, R., Briggs, P. R. and Barlow,
E. W. R. 2012. Earlier wine-grape ripening driven by climatic warming and drying and management practices. Nature Climate Change 2: 259-264.

WECS. 2002. Water Resources Strategy Nepal. Water and Energy Commission Secretariat, Government of Nepal, Kathmandu, Nepal.

WWF. Nepal, 2006. An Overview of Glaciers, Glaciers Retreat, and its Subsequent Impacts in Nepal, India and China. World Wildlife Fund Nepal, Kathmandu, Nepal.

Yadav, R. R. and Singh, J. 2002. Tree-ring analysis of Taxus baccata from the Western Himalaya, India, and its dendroclimatic potential. TreeRing Research 58 (1/2): 23-29.

Yadav, R. R., Singh, J., Dubey, B. and Chaturvedi, R. 2004. Varying strength of relationship between temperature and growth of highlevel fir at marginal ecosystems in Western Himalaya, India. Current Science 86 (8): 1152-1156. 